\section{ANALISIS PENERAPAN SISTEM INFORMASI AKUNTANSI PENGGAJIAN DALAM MENUNJANG EFEKTIVITAS PENGENDALIAN INTERNAL PENGGAJIAN}

\section{Amirah Yayang Intishar \& Muanas}

\author{
Program Studi Akuntansi \\ Sekolah Tinggi Ilmu Ekonomi Kesatuan Bogor, Indonesia \\ E-mail :lemlit@stiekesatuan.ac.id
}

Payroll accounting information system

Submitted: MAY 2018

Accepted: OCTOBER 2018

\begin{abstract}
One that influences the success of the company is the system applied to the company, the payroll accounting information system. A payroll accounting information system is very influential for companies to support the effectiveness of internal control. The author conducted research at PT. Dwi Prima Rezeky, a company engaged in the manufacturing industry. The purpose of this study was to find out the description of salary payment transactions and to find out the application of payroll accounting information systems to support the effectiveness of internal control.

This type of research is a type of descriptive research that uses primary data such as the results of interviews with companies and secondary such as organizational structure. Data collection techniques are carried out using observation, interview, and literature techniques. The data analysis method used is a descriptive method. The study was conducted at PT. Dwi Prima Rezeky is located on Jl. Raya Pemda Keradenan No. 12 Cibinong-Bogor.

The results of this study indicate that PT. Dwi Prima Rezeky has implemented a payroll accounting information system already good enough because it has implemented the elements of an adequate accounting information system so as to support the effectiveness of internal control. However, in internal control, there are still a number of functions and systems of authorization that have not been implemented, namely the function of making salary lists and salary payments carried out by the financial function and the payroll is not checked again and not re-authorized by the accounting.
\end{abstract}

Keyword: payroll accounting information system, internal control

\title{
PENDAHULUAN
}

Gaji merupakan biaya tenaga kerja dan unsur terbesar yang memerlukan ketelitian dalam penetapan, pengelompokan, pencatatan serta pembayarannya. Banyak permasalahan yang muncul terkait dengan kegiatan pembayaran gaji, seringkali terjadi penyalahgunaan oleh pihak tertentu sehingga muncul kecurangan dan penyelewengan yang dapat menimbulkan kerugian bagi perusahaan, salah pencatatan dan lain-lain. 
Payroll

accounting

information

system

$\underline{095}$

Wajar apabila perusahaan memberikan perhatian yang cukup kepada kebijakan penggajian. Oleh karena itu diperlukan informasi yang relevan dan akurat sebagai sarana komunikasi dan untuk itu perusahaan memerlukan sistem akuntansi penggajian yang baik untuk mengumpulkan, mencatat, menyimpan, mengolah data dan menghasilkan suatu informasi, guna memudahkan pengambilan keputusan. Dalam sistem akuntansi penggajian terdapat fungsifungsi yang terkait dengan sistem dan prosedur penggajian, dokumen yang digunakan dalam sistem dan prosedur penggajian, catatan yang digunakan dalam sistem dan prosedur penggajian, dan jaringan prosedur yang digunakan dalam sistem dan prosedur penggajian. Hal tersebut dapat terlaksana jika perusahaan menerapkan sistem informasi akuntansi penggajian dan pengendalian internal yang baik.

Pengendalian intern dapat dilaksanakan dengan baik apabila terdapat struktur organisasi yang jelas antara pemisahan tugas dan tanggung jawab masingmasing bagian, pencatatan yang sistematis untuk setiap transaksi keuangan, pengawasan yang rutin dari atasan kepada bawahan, kebijakan dan prosedur pengamanan, menangkap serta mengkomunikasikan informasi yang diperlukan oleh karyawan untuk melaksanakan tugasnya, juga kegiatan evaluasi untuk menilai seluruh kegiatan yang telah dilaksanakan. Setiap perusahaan sebaiknya mempunyai sistem akuntansi penggajian yang baik, untuk menghindari kemungkinan terjadinya penyimpangan dalam pelaksanaan tanggung jawab dari masing-masing bagian.

\section{TINJAUAN PUSTAKA}

\section{Sistem Informasi Akuntansi}

Sistem informasi akuntansi menurut Marshall B. Romney dan Paul John Steinbart (2016:10), adalah sistem yang digunakan untuk mengumpulkan, mencatat, menyimpan dan mengolah data untuk menghasilkan suatu informasi untuk pengambilan keputusan. Sistem ini meliputi orang, prosedur dan instruksi data perangkat lunak, infrastruktur teknologi informasi serta pengendalian internal dan ukuran keamanan.

\section{Gaji/Upah}

Gaji merupakan bagian dari kompensasi-kompensasi yang paling besar diberikan perusahaan sebagai balas jasa kepada karyawannya. Dan bagi karyawan ini merupakan nilai hak dari prestasi mereka, juga sebagai motivator dalam bekerja.

Veithzal Rivai (2010:762) menyebutkan gaji adalah balas jasa dalam bentuk uang yang diterima karyawan sebagai konsekuensi dari statusnya sebagai seorang karyawan yang memberikan konstribusi dalam mencapai tujuan perusahaan dan upah adalah balas jasa yang adil dan layak diberikan kepada para pekerja atas jasa jasanya dalam mencapai tujuan organisasi. Upah merupakan imbalan financial langsung yang dibayarkan kepada karyawan berdasarkan jam kerja, jumlah barang yang dihasilkan atau banyaknya pelayanan yang diberikan.

\section{Sistem Akuntansi Penggajian}

Menurut Mulyadi (2016 : 373) mengemukakan bahwa sistem informasi akuntansi penggajian adalah fungsi, dokumen, catatan, dan sistem pengendalian 
intern yang digunakan untuk kepentingan harga pokok produk dan penyediaan informasi guna pengawasan biaya tenaga kerja.

Sedangkan menurut Zaki Baridwan (2013 : 223) menyatakan bahwa sistem informasi akuntansi penggajian adalah fungsi, organisasi, formulir, catatan dan laporan tentang penggajian pada karyawan yang dibayar tiap bulan yang dikoordinasi sedemikian rupa untuk menyediakan informasi keuangan yang dibutuhkan oleh manajemen guna memudahkan pengelolaan perusahaan.

\section{Fungsi-fungsi yang terkait dalam sistem penggajian}

Fungsi-fungsi yang terkait dalam sistem akuntansi penggajian adalah sebagai berikut (Mulyadi, 2016: 383) :

1. Fungsi kepegawaian

Bagian ini bertanggungjawab untuk mencari karyawan baru, menyeleksi calon karyawan baru, membuat surat keputusan tarif gaji, mutasi karyawan, kenaikan pangkat dan golongan gaji, memberhentikan karyawan dan memonitoring status-status dalam penggajian.

2. Fungsi pencatat waktu

Bagian ini bertanggungjawab untuk menyelenggarakan waktu hadir bagi semua karyawan perusahaan atau instansi, sistem pengendalian intern yang baik mensyaratkan fungsi pencatatan waktu hadir karyawan tidak boleh dilaksanakan oleh fungsi operasi atau oleh fungsi pembuat daftar gaji dan upah.

3. Fungsi pembuat daftar gaji dan upah

Bagian ini bertanggungjawab untuk membuat daftar gaji dan upah yang berisi penghasilan bruto yang menjadi hak dan berbagai potongan yang menjadi beban setiap karyawan selama jangka waktu pembayaran gaji.

4. Fungsi akuntansi

Bagian akuntansi bertanggungjawab untuk mencatat kewajiban yang timbul dalam hubunganya dengan pembayaran gaji karyawan.

5. Fungsi keuangan

Bagian ini bertanggungjawab untuk mengisi cek tersebut ke bank, guna pembayaran gaji dan upah, lalu menguangkan atau mencairkan cek tersebut ke bank, uang tunai tersebut kemudian dimasukkan ke dalam amplop gaji dan upah setiap karyawan dan buruh untuk selanjutnya dibagikan kepada yang berhak.

\section{Dokumen yang digunakan dalam Sistem Penggajian}

Menurut Mulyadi (2016:374) dokumen yang digunakan dalam sistem akuntansi gaji dan upah adalah dokumen pendukung perubahan gaji dan upah, kartu jam hadir, kartu jam kerja, daftar gaji dan daftar upah, rekap daftar gaji dan rekap daftar upah, surat pernyataan gaji dan upah, amplop gaji dan upah dan bukti kas keluar.

\section{Catatan Akuntansi Yang Digunakan Dalam Sistem Penggajian}

Catatan akuntansi yang digunakan dalam pencatatan gaji dan upah adalah:

a. Jurnal umum, digunakan untuk mencatat distribusi biaya tenaga kerja ke tiap departemen dalam perusahaan.

b. Kartu harga pokok produk, digunakan untuk mencatat upah tenaga kerja langsung untuk tiap pesanan produk tertentu.

c. Kartu biaya, digunakan untuk mencatat biaya tenaga kerja tidak langsung dan biaya tenaga kerja nonproduksi tiap departemen dalam perusahaan. 
Payroll

accounting

information

system

d. Kartu penghasilan karyawan, digunakan untuk mencatat penghasilan berbagai potongan yang diterima karyawan. Informasi dalam catatan ini digunakan sebagai dasar perhitungan pph pasal 21 yang menjadi beban tiap karyawan (Mulyadi,2016:382).

\section{Jaringan Prosedur Yang Membentuk Sistem Penggajian}

Sistem akuntansi penggajian dan pengupahan terbentuk dari jaringan prosedur berikut: Prosedur pencatatan waktu hadir, prosedur pencatatan waktu kerja, prosedur pembuatan daftar gaji dan upah, prosedur distribusi gaji dan upah, prosedur pembayaran gaji dan upah.

\section{Pengendalian Internal}

Menurut Marshall B. Romney dan Paul John Steinbart (2016:229) pengendalian internal adalah rencana organisasi dan metode bisnis yang dipergunakan untuk menjaga asset, memberikan informasi yang akurat dan andal mendorong dan memperbaiki efisiensi jalannya organisasi, serta mendorong kesesuaian dengan kebijakan yang telah ditetapkan.

\section{Komponen Pengendalian Intern}

Menurut Sukrisno Agoes (2012:100), adapun penjelasan dari kelima komponen tersebut sebagai berikut :

1. Lingkungan pengendalian

Lingkungan pengendalian menetapkan corak suatu organisasi dan mempengaruhi kesadaran pengendalian orang-orangnya.

2. Penilaian Risiko

Risiko yang relevan dengan pelaporan keuangan mencakup peristiwa dan kadaan intern maupun ekstern yang dapat terjadi dan secara negatif mempengaruhi kemampuan entitas untuk mencatat, mengolah, meringkas, dan melaporkan data keuangan konsisten dengan asersi manajemen dalam laporan keuangan.

3. Aktivitas Pengendalian

Aktivitas pengendalian adalah kebijakan dan prosedur yang membantu memastikan bahwa arahan manajemen dilaksanakan. Aktivitas tersebut membantu memastikan bahwa tindakan yang diperlukan untuk menanggulangi risiko dalam tujuan entitas, sudah dilaksanakan.

4. Informasi dan Komunikasi

Informasi yang relevan dengan tujuan pelaporan keuangan, yang meliputi sistem akuntansi, terdiri atas metode dan catatan yang dibangun untuk mencatat, mengolah, meringkas, dan melaporkan transaksi entitas (baik peristiwa maupun kondisi) dan untuk memelihara akuntabilitas bagi aset, utang, dan ekuitas yang bersangkutan.

5. Pemantauan

Pemantauan adalah proses penentuan kualitas kinerja pengendalian intern sepanjang waktu. Pemantauan ini mencakup penentuan desain dan operasi pengendalian tepat waktu dan pengambilan tindakan koreksi

\section{Efektivitas}

Menurut Anthony dan Vijay Govindarajan (2012:111) pengertian efektivitas adalah sebagai berikut :

"Effectiveness is defermined by the relationship between input and output". 
Pengertian efektivitas di atas dapat juga dipahami sebagai derajat keberhasilan suatu organisasi. Dengan demikian, dapat dikaitkan bahwa semakin besar kontribusi keluaran yang dihasilkan terhadap nilai sasaran tersebut, maka dapat dikatakan semakin efektif pada unit tersebut.

\section{METODE PENELITIAN}

Metode analisis data yang digunakan dalam penelitian ini adalah metode analisis deskriptif kualitatif yang membandingkan antara teori dengan praktek diperusahaan.

Jenis data yang diperoleh, dikelompokkan menjadi dua, yaitu:

1. Data Primer

Data primer merupakan data yang langsung diperoleh dari PT. Dwi Prima

Rezeky. Pada penelitian ini data primer diperoleh dari hasil survey wawancara dengan petugas bagian keuangan.

\section{Data Sekunder}

Data sekunder adalah data yang diperoleh secara tidak langsung, baik berupa keterangan maupun literatur yang ada hubungannya dengan penelitian, dan sifatnya melengkapi atau mendukung data primer.

\section{HASIL DAN PEMBAHASAN}

Pembahasan terhadap hasil penelitian yang dilakukan di PT. Dwi Prima Rezeky yang berkaitan dengan fungsi yang terkait dengan sistem akuntansi penggajian, dokumen yang digunakan dalam sistem akuntansi penggajian, catatan akuntansi yang digunakan dalam sistem akuntansi penggajian, jaringan prosedur dalam sistem akuntansi penggajian, dan komponen pengendalian intern penggajian. Pembahasan lebih lanjut tentang berbagai hal tersebut adalah sebagai berikut:

\section{Fungsi yang Terkait dengan Sistem Akuntansi Penggajian}

Dari uraian hasil penelitian di atas maka dapat diketahui bahwa fungsifungsi yang berkaitan dengan penggajian dan pengupahan di PT. Dwi Prima Rezeky ada fungsi kepegawaian, fungsi pencatat waktu, fungsi keuangan, dan fungsi akuntansi.

\section{A. Fungsi kepegawaian}

Bagian fungsi kepegawaian dilaksanakan dengan baik oleh bagian HRD dengan menyelenggarakan seleksi dan penempatan karyawan sesuai yang dibutuhkan.

B. Fungsi pencatat waktu hadir

Bagian fungsi pencatat waktu hadir karyawan yang dilakukan oleh bagian personalia atau HRD sudah menjalankan tugasnya dengan baik, merekap semua kehadiran karyawan sehari-hari beserta melakukan perhitungan lembur karyawan.

C. Fungsi pembuat daftar gaji dan keuangan

Bagian fungsi pembuat daftar gaji dilakukan oleh bagian keuangan, namun bagian kasir juga melakukan pembayaran gaji kepada karyawan jadi ada perangkapan tugas. Hal ini dilakukan pada PT. Dwi Prima Rezeky karena 
Payroll

accounting

information

system

$\underline{099}$

dianggap lebih efisien jika yang membayarkan gaji adalah bagian yang membuat daftar gaji karena yang lebih tau rincian besaran gajinya adalah bagian keuangan.

D. Fungsi akuntansi

kas yang Bagian fungsi akuntansi telah dijalankan dengan baik karena telah melakukan pencatatan yang berhubungan dengan penggajian, menyimpan bukti-bukti pengeluaran nantinya akan dibuatkan laporan pembayaran gaji dan membuat memindah bukukan kedalam jurnal umum dan buku besar.

\section{Dokumen yang Digunakan Dalam Sistem Akuntansi Penggajian}

Dari uraian hasil analisis di atas maka dapat diketahui bahwa dokumen yang digunakan dalam proses penggajian sudah cukup memenuhi prosedur dalam mendukung pengendalin intern, karena dokumen yang dibuat oleh perusahaan sudah lengkap dan sudah sesuai dengan teori sistem akuntansi penggajian.

Dokumen-dokumen sudah dibuat oleh bagiannya masing-masing. Dokumen pendukung perubahan gaji dibuat oleh bagian kepegawaian, laporan kehadiran harian dengan mesin pencatat waktu, laporan kehadiran lembur dibuat oleh kepala produksi, laporan gaji karyawan dibuat oleh bagian keuangan, surat pernyataan gaji atau slip gaji dibuat oleh bagian keuangan, bukti kas keluar dibuat oleh bagian akuntansi.

\section{Catatan Akuntansi yang Digunakan Dalam Sistem Akuntansi Penggajian}

Catatan yang digunakan di PT. Dwi Prima Rezeky juga sama yaitu jurnal umum, buku besar dan laporan gaji karyawan oleh karena itu, sistem akuntansi penggajian yang terkait dengan catatan akuntansi telah sesuai dengan ketentuan yang harus dipenuhi.

\section{Jaringan Prosedur Dalam Penggajian}

Jaringan prosedur yang ada di PT. Dwi Prima Rezeky yaitu prosedur kepegawaian, prosedur pencatatan waktu hadir, prosedur perhitungan gaji, prosedur pembayaran gaji.

A. Prosedur pencatatan waktu hadir dilakukan oleh kepegawaian atau HRD, prosedur ini dilakukan perusahaan sudah sempurna, melakukan rekap kehadiran karyawan sehari-hari beserta merekap jam lembur karyawan setiap bulannya.

B. Prosedur perhitungan gaji belum dilakukan dengan baik oleh bagian keuangan, pembuatan daftar gaji ini berdasarkan rekap absen yang dibuat oleh bagian kepegawaian. Sebaiknya daftar gaji diotorisasi oleh fungsi kepegawaian atau bagian HRD untuk melihat nama-nama yang terdapat dalam daftar gaji telah sesuai dengan data karyawan.

Namun hal tersebut tidak dilakukan, yang mengotorisasi daftar gaji bagian keuangan itu sendiri, dengan di otorisasi oleh bagian kepegawaian atau HRD dapat mengurangi terjadinya salah saji yang dilakukan bagian penggajian dan agar dokumen yang dihasilkan dapat diandalkan.

C. Prosedur pembayaran gaji dilakukan oleh bagian keuangan, ada perangkapan tugas antara pembuat daftar gaji dan pembayaran gaji. Hal ini dilakukan karena perusahaan menganggap lebih efisien jika yang membayarkan gaji dan upah adalah bagian yang membuat daftar gaji karena yang lebih tau tentang rincian gaji dan upah yang akan diterima karyawan. 
Dari hasil penelitian diatas unsur-unsur pengendalian internal dikatakan sudah baik, namun ada fungsi pembuat daftar gaji yang belum terpisah dari fungsi pembayaran gaji dengan adanya perangkapan tugas pada perusahaan maka akan memberikan celah timbulnya tindak kecurangan dalam bagian tersebut. Maka sebaiknya perusahaan memisahkan tugas ke dalam fungsinya masing-masing, bisa dengan salah satu dari bagian kepegawaian atau HRD untuk menjadi fungsi pembuat daftar gaji dan pembayaran gaji dilakukan oleh bagian keuangan. Sehingga tidak terjadi perangkapan tugas yang dilakukan bagian keuangan dan prosedur sistem penggajian dapat mendukung efektivitas pengendalian intern.

Sistem otorisasi yang diterapkan pada PT. Dwi Prima Rezeky berjalan dengan efektif, setiap dokumen mengenai pembuatan dan pengeluaran kas harus di otorisasi terlebih dahulu oleh direktur.

Namun ada kekurangan dari segi pemotongan gaji yang seharusnya dilakukan oleh bagian kepegawaian atau HRD dan daftar gaji belum efektif karena tidak diotorisasi oleh bagian kepegawaian atau HRD. Untuk menghindari adanya penyelewengan sebaiknya daftar gaji dan potongan gaji diberikan kepada bagian kepegawaian atau HRD untuk dilakukan check terlebih dahulu atas namanama yang ada dalam dokumen daftar gaji setelah itu dilakukan pengecekan ulang oleh keuangan sebelum diuangkan, maka pengecekan dilakukan bertahap, bukan hanya dipercayakan pada satu bagian saja. Hal ini dilakukan untuk menghindari adanya penyelewengan yang mungkin bisa terjadi.

Perubahan terhadap gaji karyawan yang terjadi akibat perubahan pangkat didasarkan pada surat keputusan yang ditandatangani direktur kemudian diberikan kepada bagian keuangan yang mana ditransfer oleh bagian keuangan hal ini telah efektif.

Selain itu PT. Dwi Prima Rezeky memiliki dokumen dan catatan akuntansi yang mendukung dalam melakukan kegiatan transaksi, serta dokumen dan catatan akuntansi yang digunakan sudah sesuai dengan ketentuan yang berlaku sehingga memudahkan dalam proses pencatatan, perhitungan dan pembayaran. Kegiatan transaksi pun di proses melalui sistem komputerisasi yaitu menggunakan sistem payroll.

\section{Peranan Sistem Informasi Akuntansi Penggajian dalam Menunjang Efektivitas Pengendalian Internal Penggajian}

Peranan sistem informasi akuntansi penggajian sangat penting dalam menunjang efektivitas pengendalian internal penggajian, artinya untuk mencapai pengendalian internal penggajian yang baik PT. Dwi Prima Rezeky harus melakukan kegiatan penggajian berdasarkan sistem operasional prosedur yang telah ditentukan. Dan dari hasil penelitian yang diperoleh oleh penulis PT. Dwi Prima Rezeky telah menerapkan sistem operasional prosedur dengan baik dan sesuai dengan ketentuan yang berlaku.

Sistem informasi penggajian mempunyai peranan yang sangat penting dimana sistem informasi akuntansi berperan dalam menyediakan sumber daya manusia, data dan informasi yang memadai dan berguna dalam pengendalian internal.

PT. Dwi Prima Rezeky memiliki dokumen dan catatan akuntansi yang mendukung dalam melakukan kegiatan transaksi, serta dokumen dan catatan akuntansi yang digunakan sudah sesuai dengan ketentuan yang berlaku sehingga memudahkan dalam proses pencatatan, perhitungan, dan pembayaran. Kegiatan 
Payroll

accounting

information

system

101

transaksi pun di proses melalui sistem komputerisasi yaitu menggunakan sistem payroll.

Pengendalian internal penggajian juga telah diterapkan dengan adanya pemisahan fungsi atau pemisahan tanggungjawab fungsional. Akan tetapi dalam sistem otorisasi daftar gaji yang seharusnya dilakukan oleh personalia namun diotorisasi oleh bagian keuangan belum diterapkan diperusahaan. Untuk menghindari adanya penyelewengan sebaiknya daftar gaji diberikan kepada bagian personalia untuk dilakukan cek terlebih dahulu atas nama-nama yang ada dalam dokumen daftar gaji dan upah setelah itu dilakukan pengecekan ulang oleh bagian akuntansi, maka pengecekan dilakukan bertahap, bukan hanya dipercayakan pada satu bagian saja.

Hal ini dilakukan untuk menghindari adanya penyelewengan yang mungkin bisa terjadi. Adanya perangkapan tugas dalam prosedur pembuatan daftar gaji dan pembayaran gaji, dengan adanya perangkapan tugas pada perusahaan maka akan memberikan celah timbulnya tindak kecurangan dalam bagian tersebut.

Maka sebaiknya perusahaan memisahkan tugas ke dalam fungsinya masingmasing, bisa dengan salah satu dari bagian personalia ditugaskan untuk menjadi fungsi pembuatan daftar gaji dan pembayaran gaji dilakukan oleh bagian keuangan. Sehingga tidak terjadi perangkapan tugas yang dilakukan bagian keuangan dan prosedur sistem penggajian dapat mendukung efektivitas pengendalian intern.

Dengan demikian dijalankannya sistem informasi akuntansi yang memadai maka akan menunjang efektivitas pengendalian internal penggajian. Efektivitas pengendalian internal akan tercapai apabila tujuan pengendalian internal tercapai.

\section{SIMPULAN DAN SARAN}

\section{Simpulan}

Berdasarkan hasil analisis dan pembahasan di atas, dapat diambil kesimpulan sebagai berikut:

1. Fungsi yang terkait sistem penggajian pada PT. Dwi Prima Rezeky sudah seluruhnya menjalankan tugas dengan baik akan tetapi ada bagian yang masih merangkap tugas yang dilakukan bagian keuangan yakni sebagai pembuat daftar gaji juga pembayaran gaji.

Dokumen dan catatan akuntansi yang digunakan pada sistem penggajian pada PT. Dwi Prima Rezeky sudah cukup baik seperti daftar hadir, daftar gaji, laporan penggajian, slip gaji,laporan pembayaran gaji, jurnal dan buku besar. Keseluruhan dokumen tersebut sudah terprogram dalam komputer, sehingga dapat meminimalkan kesalahan dalam pembayaran gaji.

2. Sistem pencatatan waktu sudah baik menggunakan mesin pencatat waktu (finger print), tidak adanya pengawasan khusus dibagian absensi dikarenakan absensi menggunakan finger print karyawan tidak akan curang dalam melakukan absensi. Terkecuali mesin sedang eror.

3. Penerapan pengendalian intern penggajian pada PT. Dwi Prima Rezeky dilihat dari wewenang dan prosedur penggajian pada perusahaan ini sudah baik, akan tetapi daftar gaji tidak dicek kembali dan tidak diotorisasi oleh bagian akuntansi. 


\section{Saran}

Berdasarkan beberapa kesimpulan diatas, maka saran yang dapat peneliti berikan untuk dijadikan masukan bagi pihak perusahaan sebagai berikut:

1. Sebaiknya fungsi pembuatan daftar gaji diperlukan oleh perusahaan, bisa dengan salah satu dari bagian kepegawaian atau HRD ditugaskan untuk menjadi fungsi pembuat daftar gaji dan pembayaran gaji dilakukan oleh bagian keuangan. Sehingga tidak terjadi perangkapan tugas yang dilakukan bagian keuangan.

2. Apabila mesin pencatat waktu (finger print) sedang rusak maka sebaiknya dilakukan pengawasan khusus, hal ini dapat menyebabkan kecurangan dalam pencatatan waktu, sehingga dapat merugikan perusahaan karena memberikan gaji kepada karyawan lebih atau kurang.

3. Sebaiknya daftar gaji diberikan kepada bagian akuntansi untuk dilakukan cek terlebih dahulu dan mengotorisasi atas nama-nama yang ada dalam dokumen daftar gaji setelah itu dilakukan pengecekan ulang oleh keuangan sebelum ditransfer, maka pengecekan dilakukan bertahap, bukan hanya dipercayakan pada satu bagian saja. Hal ini dilakukan untuk menghindari adanya penyelewengan yang mungkin bisa terjadi.

\section{DAFTAR PUSTAKA}

Agoes, Sukrisno. (2012). Auditing (4 ed.). Jakarta: Salemba Empat.

Arens, Alvin A. dan James K. Loebbecke. (2010). Auditing and Assurance Service. Jakarta: Erlangga.

Baridwan, Zaki. (2013). Sistem Informasi Akuntansi (Kedua ed.). Yogyakarta.

Elfreda, Fedora. (2016). Analisis Sistem dan Prosedur Penggajian dan Pengupahan dalam Upaya Meningkatkan Pengendalian Intern. Jurnal Administrasi Bisnis (JAB), 41.

Govindarajan, Vijay dan Anthony. (2012). Sistem Pengendalian Manajemen. Jakarta: Salemba Empat.

Herdianto, Rendy Bagus. (2015). Analisis Sistem Akuntansi Penggajian dan Pengupahan untuk Menunjang Pengendalian Intern Perusahaan.

Hidayat, Mohammad Taufiq. (2013). Analisis Penerapan Sistem Akuntansi Penggajian dan Pengupahan dalam Mendukung Pengendalian Intern. Jurnal Administrasi Bisnis (JAB) , 6.

Krismiaji. (2010). Sistem Informasi Akuntansi (3 ed.). Sekolah Tinggi Ilmu Manajemen YKPN, Yogyakarta.

Mahmudi. (2005). Manajemen Kinerja Sektor Publik. Yogyakarta: UPP AMP YKPN.

Mulyadi. (2008). Sistem Akuntansi. Jakarta: Salemba Empat.

Mulyadi. (2016). Sistem Akuntansi. Jakarta: Salemba Empat.

Priantara, Diaz. (2013). Froud Auditing and Investigation. Jakarta: Mitra Wacana Media.

Puspaningrum, Rizky Ayu. (2013). Penerapan Sistem Informasi Akuntansi Penggajian dalam Pelaksanaan Pengendalian Intern pada PT Kebon Agung. Jurnal Ilmu \& Riset Akuntansi , 2.

Rivai, Veithzal. (2010). Manajemen Sumber Daya Manusia untuk Perusahaan. Jakarta: PT. Raja Grafindo Persada. 
Payroll accounting information system

$\underline{103}$
Saraswati, Kumala Mega. (2014). Analisis Sistem Akuntansi Penggajian \& Pengupahan Karyawan dalam Usaha Meningkatkan Pengendalian Intern Perusahaan. Jurnal Administrasi Bisnis (JAB) , 8.

Serdamayanti. (2009). Sumber Daya Manusia dan Produktivitas Kerja. Bandung: CV Mandar Maju.

Steinbart, John dan Marshall B. Romney. (2016). Sistem Informasi Akuntansi (13 ed.). Jakarta: Salemba Empat.

Susanto, Azhar. (2007). Sistem Informasi Akuntansi. Bandung: Lingga Jaya.

Susanto, Azhar. (2013). Sistem Informasi Akuntansi. Bandung: Lingga Jaya.

https://gajimu.com/main/pekerjaan-yanglayak/upah-kerja/pertanyaan-mengenaigaji-atau-upah-kerja-1 